\section{Eperythrozoon parvum, a Filterable Blood Parasite of Swine}

INFORMATroN relative to the filterability of species of the genus Eperythrozoon apparently has not been published previously ${ }^{1}$. These blood parasites are classified $^{1}$ in the order Rickettsiales, a group which includes numerous filterable agents. It is apparent that passage or retention of Eperythrozoon by the usual bacteriological filters would not serve as any criterion for altering their present classification.

Foote et al. ${ }^{2}$ reported that the parasites of swine, Eperythrozoon suis Splitter and Eperythrozoon parvum Splitter, were both filterable through 12-lb. Mandler and possibly finer filters. This observation was made in connexion with studies on a condition of swine termed by these workers "virus anemia". However, the infectious nature of eperythrozoa was not recognized and these parasites were referred to as "artefacts" or "reactionary bodies".

A study was made of the filterability of $E$. suis and $E$. parvum in swine blood serum. Details of the filtration procedures are given in a report of this work ${ }^{3}$. At negative pressures not exceeding $100 \mathrm{~mm}$. of mercury, $E$. parvum was found capable of traversing the 8-, 12- and 14-1b. Mandler candles. Passage was also effected through the medium $(N)$ and fine $(W)$ Berkefeld candles, and the Seitz EK. The parasite was also recovered on double filtration through two 8-1b. Mandler candles in one instance, and two 12-lb. Mandlers in another. Complete retention was obtained on double filtration with the Seitz $E K$. These filters DIFFERENTIATION OF Eperythrozoon suis AND Eperythrozoon parvum

\begin{tabular}{|c|c|c|}
\hline & E. suis & E. parvum \\
\hline Morphology & $\begin{array}{l}\text { Large rings }(0 \cdot 8-1 \cdot 0 \mu) \\
\text { with much chrom- } \\
\text { atin. Discoid forms } \\
\text { and very large irreg- } \\
\text { ular rings }(2-3 \mu) \text { may } \\
\text { be present }\end{array}$ & $\begin{array}{l}\text { Small rings }(0.5-0.8 \mu) \\
\text { with numerous coccus } \\
\text { forms of considerably } \\
\text { smaller size. Often } \\
\text { found in large numbers } \\
\text { on single erythrocytes } \\
\text { when organisms are rare } \\
\text { in blood }\end{array}$ \\
\hline $\begin{array}{l}\text { Patho: } \\
\text { genicity }\end{array}$ & $\begin{array}{l}\text { Consistently patho- } \\
\text { genic in heavy in- } \\
\text { fections in splenecto- } \\
\text { mized or non-splen- } \\
\text { ectomized pigs. Etio- } \\
\text { logical agent of acute } \\
\text { eperythrozoonosis of } \\
\text { swine in the field }\end{array}$ & $\begin{array}{l}\text { Relatively non-patho- } \\
\text { genic. May produce } \\
\text { mild to severe anæmia } \\
\text { in some experimental } \\
\text { cases. Not known to } \\
\text { produce acute epery. } \\
\text { throzoonosis in the fleld }\end{array}$ \\
\hline $\begin{array}{l}\text { Prepatent } \\
\text { period }\end{array}$ & $\begin{array}{l}6 \cdot 1 \text { days (average of } 43 \\
\text { initial attacks) }\end{array}$ & $\begin{array}{l}13 \cdot 1 \text { days (average of } 21 \\
\text { initial attacks) }\end{array}$ \\
\hline $\begin{array}{l}\text { Patent rise } \\
\text { of infection }\end{array}$ & $\begin{array}{l}3 \cdot 3 \text { days (average of } 43 \\
\text { initial attacks) }\end{array}$ & $\begin{array}{l}7 \cdot 0 \text { days (average of } 21 \\
\text { initial attacks) }\end{array}$ \\
\hline $\begin{array}{l}\text { Incubation } \\
\text { period }\end{array}$ & $\begin{array}{c}9 \cdot 7 \text { days (average of } 43 \\
\text { experimental cases) }\end{array}$ & $\begin{array}{c}26 \cdot 6 \text { days (average of } 3 \\
\text { experimental cases) }\end{array}$ \\
\hline $\begin{array}{l}\text { Susceptibil- } \\
\text { ity to Neo- } \\
\text { arsphen- } \\
\text { amine }\end{array}$ & $\begin{array}{l}\text { Highly suceptible to } \\
\text { doses of } 15 \mathrm{mgm} . / \\
\mathrm{kgm} \text {. or greater }\end{array}$ & $\begin{array}{l}\text { Relatively resistant. } \\
\text { Doses of } 4 \mathrm{c}-45 \mathrm{mgm} \text {./ } \\
\text { kgm. are effective ir } \\
\text { regularly }\end{array}$ \\
\hline $\begin{array}{l}\text { Cross } \\
\text { immunity }\end{array}$ & $\begin{array}{l}\text { Pigs pre-mune with } E \text {. } \\
\text { suis are readily in- } \\
\text { fected with } E \text {. parvum }\end{array}$ & $\begin{array}{l}\text { Pigs pre-mune with } E \text {. } \\
\text { parvum are readily sus- } \\
\text { ceptible to acute and } \\
\text { fatal infection with } E \text {. } \\
\text { suis }\end{array}$ \\
\hline Interference & $\begin{array}{l}E \text {. suis displaces } E \text {. } \\
\text { parvum when infection } \\
\text { is superimposed }\end{array}$ & $\begin{array}{l}E . \text { parvum is suppressed } \\
\text { in initial mixed in } \\
\text { fections with } E . \text { suis }\end{array}$ \\
\hline Filterability & $\begin{array}{l}\text { Usually retained by } \\
\text { the fine diatomaceous } \\
\text { earth fllters and the } \\
\text { Seitz } E K \text { at negative } \\
\text { pressures of } 100 \mathrm{~mm} \text {. } \\
\text { mercury }\end{array}$ & $\begin{array}{l}\text { Readily passes the fine } \\
\text { diatomaceous earth fil- } \\
\text { ters and the Scitz } E K \\
\text { Uncomplicated strain } \\
\text { may be } \epsilon \text { sablished by } \\
\text { filtration of serum con- } \\
\text { taining the two species }\end{array}$ \\
\hline
\end{tabular}

completely retained Serratia marcescens in saline ( 300 million bacteria per c.c.) adjusted to the approximate $p \mathrm{H}$ of swine serum $(p \mathrm{H} 7 \cdot 4)$.

In one instance $E$. suis passed the $N$-Berkefeld, but was retained by the Seitz $E K$. In another experiment, passage was effected through the 8-lb. Mandler, but not the 14-1b. Mandler, the $W$-Berkefeld, or the Seitz $E K$. In an additional trial, the parasite traversed the 8-and 14-lb. Mandlers, but was retained by the $W$-Berkefeld and the Seitz $E K$. E. suis was not recovered in nine other filtration experiments from serum or serum filtrates of known carriers or acute experimental cases.

$E$. parvum was repeatedly separated from $E$. suis and established in a pure, uncomplicated infection by filtering the serum portion of blood known to contain both species. In several experiments involving microscopically negative carriers, eperythrozoa were recovered from the cellular portion of blood only; the unfiltered serum was not infectious. This is regarded as additional evidence of the infectious nature of the Eperythrozoon structure, since these blood forms possess a distinct affinity for the erythrocyte.

As a result of these studies, additional information has been compiled relative to the differentiation of $E$. suis from $E$. parvum. This is summarized in the accompanying table.

\section{EArL J. Splitter}

Department of Veterinary Medicine, Kansas Agricultural Experiment Station, Manhattan, Kansas.

Dec. 30.

1 Breed, R. S., Murray, E. G. D., Fitchens, A. P., and the Society of American , Bacteriolozists, "Bergey's Manual of Determinative ${ }^{2}$ Foote, I. E., Brock, W. E., and Gallaher, B., North Amer. Vet., 82 , 17 (195i).

${ }^{3}$ Splitter, E. J., Amer. J. Vet. Res., 13, 290 (1952).

\section{Reversal of the Heart-beat in Tunicates}

THE periodic reversal of the heart-beat in Tunicates has been considered by us $^{1}$ on the basis of the backpressure theory originally propounded by Lahille ${ }^{2}$. Recently, Millar ${ }^{3}$ has concluded from experiments on isolated hearts of Ciona intestinalis that the backpressure theory is untenable.

Although we failed to observe reversals in isolated hearts of Ascidiella aspersa, we stated that we saw no reason to suppose that they should not occur. We would not, however, expect them to be regular, and in fact the results quoted by Millar give periods ranging from $1 \frac{1}{2}$ to $18 \frac{1}{2}$ minutes between reversals. These reversals occurred after several hours of oneway beating, a fact which is in agreement with the back-pressure theory, and only when the heart is very abnormal does the reversal effect become apparent.

It is important to realize the scope of the back. pressure theory. As we have pointed out ${ }^{1}$, it merely gives a reason for the stopping of the beat in a particular direction. How the opposite beat afterwards takes over is not explainable in terms of the theory, nor in fact is the mechanism by means of which successive beats one way dominate until reversal. 